Berkala Ilmu Perpustakaan dan Informasi, Vol. 15, No. 2, Desember 2019, Hal. 188-200 DOI: 10.22146/bip.40525

ISSN 1693-7740 (Print), ISSN 2477-0361 (Online)

Tersedia online di https://jurnal.ugm.ac.id/bip

\title{
Dekonstruksi titik akses diseminasi informasi pada Radio Boekoe
}

\author{
Rukiyah, Ana Irhandayaningsih, Lydia Christiani \\ Program Studi Ilmu Perpustakaan, Fakultas Ilmu Budaya, Universitas Diponegoro \\ e-mail: lydia.christiani@live.undip.ac.id
}

Naskah diterima: 5 November 2018, direvisi: 9 Oktober 2019, disetujui: 4 November 2019

\begin{abstract}
ABSTRAK
Pendahuluan. Radio Boekoe sebagai komunitas yang terimbas dampak determinasi teknologi informasi, beradaptasi melalui proses dekonstruksi titik akses diseminasi informasi dengan memanfaatkan media hibrida. Penelitian ini bertujuan membahas proses dekonstruksi titik akses diseminasi informasi pada Radio Boekoe.

Metode penelitian. Penelitian ini menggunakan metode penelitian kualitatif studi kasus. Pengumpulan data dilakukan melalui observasi, wawancara, dan studi dokumentasi. Informan penelitian ini yaitu pendiri, pengelola dan volunteer Radio Boekoe.

Data Analisis. Data penelitian dianalisis dengan tahapan reduksi, display, dan penarikan kesimpulan.

Hasil dan Pembahasan. Proses dekonstruksi titik akses informasi pada Radio Boekoe terjadi melalui pemanfaatan media hibrida. Proses dekonstruksi titik akses informasi diperluas hingga proses penambahan kapasitas akses informasi dalam wujud co-working space Bale Black Box.

Kesimpulan dan Saran.Proses dekonstruksi titik akses informasi pada Radio Boekoe terjadi melalui pergeseran titik akses lokal berupa Gelaran Iboekoe menjadi akses global berbasis media hibrida dalam wujud radio internet. Selanjutnya disarankan agar dilakukan penelitian untuk menguji efekstivitas pemanfaatan media hibrida untuk memperluas titik akses informasi.
\end{abstract}

Kata Kunci: Diseminasi informasi; Akses informasi; Media hibrida; Radio Boekoe

\begin{abstract}
Introduction. Radio Boekoe as a community that affected by the determination of information technology, adapts through the deconstruction process of information dissemination access points by utilizing hybrid media. This study aims to discuss the deconstruction process of information dissemination access points on Radio Boekoe.

Research methods. This research used a qualitative method with case study approach. The process of collecting data involved observations, interviews, and documentation studies. The informants are the founder, manager and volunteer of Radio Boekoe.

Data Analysis. The research data was analyzed with the stages of reduction, display, and drawing conclusions.

Results and Discussions. The deconstruction process of information access points on Radio Boekoe occurred through the use of hybrid media. The deconstruction process of the information access point was expanded to the process of adding information access capacity in the form of Bale Black Boxco-working space.

Conclusions. The process of deconstruction of information access points on Radio Boekoe occurs through the shifting of local access points in the form of the Gelaran Iboekoe to global hybrid media-based access in the form of internet radio. Furthermore, it is recommended to conduct a research to examine the effectiveness of using hybrid media to expand information access points.
\end{abstract}

Keywords: Information dissemination; Information access; Hybrid media; Radio Boekoe 


\section{A. PENDAHULUAN}

Manusia dan informasi adalah dua hal yang tidak terpisahkan karena sejatinya informasi tercipta dan berada di dalam benak manusia. Seiring perkembangan zaman dan peradaban manusia, informasi pun turut berkembang, perkembangan tersebut juga berimbas pada perkembangan media penyimpan informasi. Manusia tidak hanya berperan dalam penciptaan informasi, tetapi manusia juga memikirkan tentang menyimpan dan menyebarluaskan informasi yang ada di dalam benak pikirannya (Sudarsono, 2017). Peran manusia dalam penyimpanan dan penyebarluasan informasi pada akhirnya bersentuhan dengan predikat manusia sebagai homo faber yang merujuk kepada manusia sebagai pencipta dan pengguna alat (Saputro, 2011), atau yang pada perkembangannya lebih dikenal dengan sebutan teknologi. Manusia dan teknologi adalah sesuatu hal yang inheren.Predikat homo faber semakin menegaskan bahwa manusia tidak dapat lepas dari teknologi. Hal tersebut juga memiliki implikasi praktis pada cara yang ditempuh manusia dalam menciptakan, menyimpan dan menyebarluaskan informasi yang berada di alam pemikirannya.

Hubungan manusia dengan teknologi dalam ranah penciptaan, penyimpanan dan penyebarluasan (diseminasi) informasi memiliki andil yang besar pada perkembangan media karier informasi. Seperti yang diungkapkan oleh Straubhaar, LaRose, \& Davenport (2015) bahwa inherenitas manusia dan teknologi mendorong terjadinya evolusi media komunikasi sebagai wujud perkembangan media transfer informasi. Kemunculan internet yang diklaim sebagai puncak evolusi media rekam informasi merujuk pada kemampuan internet untuk menyediakan akses global, sehingga hal tersebut memungkinkan perluasan titik akses dalam proses distribusi informasi (Ruben, 2017). Puncak evolusi media rekam informasi juga memunculkan adanya media hibrida (Leeuwis, 2013) yang bercirikan kombinasi potensi yang ditawarkan media massa dan komunikasi interpersonal. Munculnya media hibrida yang merupakan implikasi determinisme teknologi informasi dan komunikasi ini menawarkan inovasi baru terkait titik akses pada proses diseminasi informasi, sebut saja kemunculan televisi internet maupun radio internet yang merupakan contoh bentuk media hibrida hasil penggabungan media massa konvensional (televisi dan radio) dengan internet. Salah satu media hibrida yang berkembang di Indonesia adalah Radio Boekoe (baca: buku).

Radio Boekoe, atau yang lebih sering disebut Radio Iboekoe oleh pendengarnya, diresmikan pada tahun 2011 dengan fokus tujuan untuk mendokumentasikan buku. Radio internet yang pada awal berdirinya memiliki kantor sekretariat di jalan Petehan Yogyakarta ini mendokumentasikan buku melalui diskusi pada program-program acara radio yang telah dirancang. Radio Boekoe merupakan bentuk pengembangan dari embrio perpustakaan berbasis komunitas atau yang lebih dikenal dengan taman bacaan bernama "Gelaran Iboekoe" yang didirikan pada 23 April 2009 (Utami, 2017). Proses dekonstruksi akses informasi dari membaca informasi dalam buku menjadi mendengarkan informasi yang terdapat dalam sebuah buku dilakukan oleh Radio Boekoe. Jalan melebarkan sayap dari sebuah taman bacaan menjadi radio internet yang dilakukan oleh penggagas "Gelaran Iboekoe" semata-mata dilandasi oleh semangat untuk mendokumentasikan buku dengan cara menyebarkannya, tidak hanya melalui darat namun juga lewat udara. Proses dekonstruksi akses informasi dengan menginisiasi media hibrida yang dilakukan Radio Boekoe untuk mendiseminasikan informasi dalam buku menarik untuk dikaji lebih lanjut, sehingga penelitian ini memiliki tujuan untuk menganalisis proses dekonstruksi titik akses diseminasi informasi melalui pemanfaatan media hibrida pada lembaga dokumentasi berbasis komunitas dengan mengkaji kasus pada Radio Boekoe. Hasil penelitian ini berdasarkan pada fakta yang ditemukan di lapangan, sehingga bersifat original.

\section{B. TINJAUAN PUSTAKA}

Akses terhadap informasi telah menjadi salah satu kebutuhan primer bagi setiap 
orang. Kebutuhan akan informasi, hiburan, pendidikan, dan akses pengetahuan dari ragam wilayah yang berbeda menjadi kebutuhan yang harus dipenuhi (Saepudin dkk., 2018).Tanpa disadari, manusia sudah terpengaruh segala sesuatu yang dibawa oleh perkembangan teknologi (Surahman, 2016), termasuk dalam proses mengakses informasi. Segala tindakan dan kejadian yang dilakukan manusia akibat pengaruh perkembangan teknologi merupakan bentuk determinasi teknologi (McLuhan, 2017), yang memunculkan penemuan inovasi-inovasi teknologibaru.

Masing-masing penemuan teknologi selalu dipertimbangkan untuk memperluas beberapa kemampuan dan kecakapan manusia. Seperti halnya penemuan media hibrida dalam ranah teknologi komunikasi (Marchetti \& Ceccobelli, 2016) yang dapat menyediakan pesan dan membentuk perilaku manusia. Misalnya media radio yang menyediakan pesan kepada khalayak manusia lewat indera pendengaran (audio), media fotografi yang menyediakan pesan kepada khalayak manusia melalui gambar (visual) maupun televisi yang menyediakan pesan kepada khalayak manusia tidak hanya lewat indera pendengaran, tetapi juga penglihatan (audiovisual). Kehadiran media baru menjadikan informasi sebagai sesuatu yang mudah dicari dan terbuka (Widjanarko, dkk., 2013). Hal ini sejalan dengan pernyataan Chadwick (2013) bahwa, "Power in the hybrid media system is exercised by those who are successfully able to create, tap, or steer information flows in ways that suit their goals and in ways that modify, enable, or disable others' agency, across and between a range of older and newer media settings".

Media hibrida merupakan sebuah kekuatan inovasi baru yang mampu menggerakkan pesanpesan melintasi ruang dan waktu dengan maksud mencapai tujuan efektivitas dan efisiensi serta lebih ekonomis untuk dapat menyampaikan pesan-pesan yang ditujukan untuk menggerakkan masyarakat (Leeuwis, 2013). Media hibrida menyebabkan diseminasi informasi lebih berpihak pada kepentingan masyarakat.Diseminasi informasi sebagai suatu kegiatan yang ditujukan kepada kelompok target atau individu untuk memperoleh informasi, menimbulkan kesadaran pada individu tersebut, menerima informasi tersebut, dan pada akhirnya memanfaatkan informasi tersebut.

Kehadiran media hibrida sebagai hasil determinisme teknologi memberikan pengaruh yang besar kepada masyarakat (McLuhan, 2017), terutama terkait kekuatan khalayak dalam memproduksi informasi dan menyebarluaskannya (diseminasi informasi). Keberadaan media hibrida yang semula dimanfaatkan khalayak sebatas pada interaksi sosial (Nasrullah, 2015), secara perlahan berubah menjadi saluran pemberitaan yang mampu memicu proses dekonstruksi titik akses informasi dengan berperan sebagai saluran alternatif media massa yang menjanjikan titik akses diseminasi informasi baru yang memiliki jangkauan yang lebih luas.

\section{METODE PENELITIAN}

Penelitian ini dilakukan berdasarkan desain metode penelitian kualitatif untuk memahami proses dekonstruksi titik akses diseminasi informasi melalui siaran Radio Boekoe secara lebih mendalam dengan pendekatan studi kasus. Desain penelitian studi kasus yang digunakan dalam penelitian ini adalah desain studi kasus tunggal yaitu penelitian yang menggunakan sebuah kasus untuk menggambarkan suatu isu atau perhatian (Gunawan, 2015).

Metode penelitian studi kasus digunakan dalam penelitian ini untuk mengungkapkan proses dekonstruksi titik akses diseminasi informasi melalui kasus Radio Boekoe kepada masyarakat. Pemilihan informan dalam penelitian ini menggunakan teknik purposive sampling, yaitu dipilih dengan pertimbangan dan tujuan tertentu (Yin, 2014). Adapun informan yang dipilih adalah pendiri, pengelola serta volunteer Radio Boekoe. Dalam penelitian ini, proses pengumpulan data tentang proses dekonstruksi titik akses informasi yang dilakukan Radio Boekoe diperoleh melalui observasi, wawancara, dan studi dokumentasi. Ketiga metode pengumpulan data yang digunakan dalam penelitian ini juga 
dimanfaatkan untuk proses uji keabsahan data melalui proses triangulasi dengan memanfaatkan, membandingkan, dan mengecek balik derajat kepercayaan informasiinformasi (Moleong, 2013) tentang proses dekonstruksi titik akses informasi yang dilakukan Radio Boekoe. Dalam penelitian ini, uji keabsahan data dilakukan dengan triangulasi sumber dan triangulasi teknik (Sugiyono, 2012).

Triangulasi sumber dalam penelitian ini dilakukan dengan mengomparasikan hasil temuan data dari informan yang satu dan informan lainnya mengenai akses informasi via program-program Radio Boekoe. Proses triangulasi sumber dilakukan untuk memperoleh persamaan maupun perbedaan data dari informan untuk selanjutnya dideskripsikan, dikategorikan berdasarkan pandangan yang sama atau berbeda, dan yang spesifik. Adapun triangulasi teknik dilakukan dengan mengungkapkan data melalui wawancara dengan para informan, lalu dicek dengan hasil observasi dan kajian dokumen tentang akses informasi via program-program Radio Boekoe, yang kemudian dilakukan analisis data untuk memperoleh keabsahan data. Setelah diperoleh data-data penelitian yang absah, data-data penelitian diolah dan dianalisis dengan mengorganisasikan dan mengurutkan data ke dalam pola, kategori, dan satuan uraian dasar (Almanshur \& Djunaidi, 2012), sehingga dapat ditemukan koherensi data penelitian yang dapat menjawab rumusan masalah penelitian tentang proses dekonstruksi titik akses informasi pada kasus Radio Boekoe.

\section{HASIL DAN PEMBAHASAN}

Radio Boekoe (baca: buku) merupakan salah satu program dari Yayasan Indonesia Buku, atau yang lebih sering disebut dengan akronim Yayasan Iboekoe (memiliki kesamaan arti dengan ibu saya). Hal ini pula yang menyebabkan Radio Boekoe lebih dikenal dengan sebutan Radio Iboekoe, yang merujuk pada akronim yayasan penaungnya. Yayasan Indonesia Buku didirikan pada April 2006 oleh Taufik Rahzen, Dipo Andy, Galam Zulkifli, Eddy Susanto, dan Muhidin M. Dahlan. Radio Boekoe merupakan radio internet yang merupakan bentuk pengembangan dari perpustakaan berbasis komunitas bernama "Gelaran Iboekoe" (Gelaran Indonesia Boekoe) yang didirikan pada 23 April 2009.

Yayasan Indonesia Buku lahir dari semangat mendokumentasikan buku para penggagasnya. Taufik Rahzen, Dipo Andy, Galam Zulkifli, Eddy Susanto, dan Muhidin M. Dahlan memiliki kesamaan visi yang memandang bahwa sebelum seseorang menghasilkan suatu karya sebagai bentuk ekspresi pemikiran dan perasaannya, baik dalam bentuk karya tulis, karya lukis, karya seni kriya, serta ekspresi-ekspresi yang lainnya, selalu membutuhkan laboratorium yang dapat mengakomodir kebutuhan pasokan informasi yang cukup untuk berekspresi.

Berawal dari pengalaman interaksi pribadi para penggagas Yayasan Indonesia Buku dengan arsip dan buku-buku di perpustakaan yang telah banyak berkontribusi dalam proses lahirnya karya-karya sastra dan karya-karya seni hasil karya para penggagas Yayasan Indonesia Buku. Melalui Yayasan Indonesia Buku, para penggagasnya ingin membagikan pengalaman interaksi pribadi mereka dengan arsip dan buku kepada masyarakat, dengan tujuan membantu masyarakat mengalami pengalaman proses kelahiran karya yang telah mereka alami secara pribadi. Cita-cita tersebut dibangun dengan harapan akan ada lebih banyak karya-karya hasil ekspresi masyarakat yang dapat menjadi titik-titik akses informasi baru, yang pada akhirnya akan bermuara pada perkembangan pengetahuan di tengah masyarakat. Perkembangan pengetahuan di tengah masyarakat inilah yang menjadi wujud nyata kelahiran inovasi-inovasi baru sebagai hasil interaksi masyarakat dengan sumbersumber informasi.

Bermula dengan mengorganisir buku-buku serta koran-koran lama yang menjadi referensi utama pada saat para penggagas Yayasan Indonesia Buku menyusun tugas akhir sebagai syarat memperoleh gelar kesarjanaan, muncul ide untuk membuat sebuah perpustakaan pribadi sebagai "laboratorium" karya. Ide tersebut mulai diwujudkan dengan menyusun bukubuku dan koran-koran lama milik pribadi para 
penggagas Yayasan Indonesia Buku yang kemudian diupayakan untuk ditempatkan pada suatu ruangan khusus. Ruangan khusus tersebut pada awalnya bertempat di Jalan Patehan, Yogyakarta. Semangat mendokumentasikan referensi berupa buku-buku dan koran lama milik masing-masing penggagas Yayasan Indonesia Buku merupakan bentuk tahap penyimpanan informasi sekaligus konstruksi awal titik akses informasi yang dilakukan oleh para penggagas Yayasan Indonesia Buku.

Langkah membangun perpustakaan di Jalan Patehan tersebut, lambat laun dirasakan kurang memberi dampak signifikan bagi pengembangan pengetahuan di tengah masyarakat, hal inilah yang kemudian mendorong diselenggarakannya Gelaran Indonesia Buku atau yang lebih familiar disebut "Gelaran Iboekoe" pada 23 April 2009. Konsep "gelaran" (bahasa Jawa untuk lapak pedagang kaki lima yang menghamparkan barang dagangannya) diselenggarakan dalam rangka mendekatkan buku kepada masyarakat. Konsep "kaki lima" yang diusung dalam Gelaran Iboekoe dilakukan agar masyarakat lebih nyaman dalam berinteraksi dengan titik-titik sumber informasi yang terdapat pada bukubuku yang digelar.

Gelaran Iboekoe merupakan langkah dekonstruksi titik akses informasi yang pertama dilakukan oleh para penggagas Yayasan Indonesia Buku. Buku-buku yang semula hanya dapat diakses oleh pengunjung basecamp Yayasan Indonesia Buku yang berada di jalan Patehan Yogyakarta, kini diupayakan untuk dapat dinikmati oleh ruang lingkup masyarakat yang lebih luas dengan prinsip "jemput bola" melalui penyelenggaraan Gelaran Iboekoe. Buku-buku dan arsip koran lama yang semula hanya diupayakan penyimpannannya saja untuk melestarikan titik akses informasinya bagi masyarakat, dengan penyelenggaraan Gelaran Iboekoe mulai didekonstruksi menuju proses diseminasi informasi.

Upaya dekonstruksi titik akses informasi melalui penyelenggaraan Gelaran Iboekoe, menghadapai tantangan perkembangan teknologi informasi dan komunikasi yang semakin pesat di Indonesia, sepanjang tahun
2009. Perkembangan teknologi informasi dan komunikasi mulai dikembangkan berbasis 2.0, sehingga menginisiasi lahirnya media hibrida. Media Hibrida memungkinkan perpaduan dua jenis atau lebih media massa konvensional dengan internet sebagai basis baru penyebarluasan informasi. Media tersebut diklaim lebih mampu mengakomodir babak perkembangan teknologi informasi dan komunikasi 2.0. Perkembangan era informasi dan komunikasi babak baru tersebut turut mendorong pemikiran lebih lanjut para penggagas Yayasan Indonesia Buku untuk mengikuti perkembangan zaman dengan menginisiasi media hibrida dalam proses penyebarluasan informasi yang tersimpan pada Warung Arsip dan perpustakaan Gelaran Iboekoe. Bentuk inisiasi perkembangan media hibrida tersebut dirintis dengan lahirnya Radio Boekoe. Kelahiran Radio Boekoe merupakan bentuk dekonstruksi titik akses informasi yang dilakukan oleh para penggagas Yayasan Indonesia Buku.

Radio Boekoe merupakan radio berbasis internet atau yang biasa disebut dengan Live Streaming Radio dan merupakan radio berbasis internet pertama di Indonesia yang mengangkat tema perbukuan dan seputar buku. Inisiasi penyelenggaraan Live Streaming Radio tersebut berawal dari sebuah prinsip bahwa buku sebagai sumber ilmu memiliki kisah yang luar biasa. Hal inilah yang menggugah pemikiran para penggagas Radio Boekoe untuk menggunakan Live Streaming Radio sebagai media menyiarkan buku dan kisah-kisah di balik proses penulisan buku tersebut. Mulai dari ide dasar hingga efek buku tersebut bagi pembacanya. Hal ini dimaksudkan agar orang tidak mudah melupakan kisah-kisah ekspresi pikiran dan perasaan manusia yang dituangkan ke dalam sebuah buku. Oleh karena itu, Radio Boekoe mengukuhkan diri sebagai lembaga yang memiliki fungsi utama mengabarkan dan mengarsipkan "suara" buku, sebagai bentuk kumandang literasi bagi masyarakat.

Radio Boekoe mengusung visi "Memasyarakatkan Buku Lewat Radio" dengan tagline "Mendengarkan Buku Membuka Cakrawala". Diawali dengan pembuatan studio 
radio yang representatif untuk rekaman dan siaran pada Bulan Oktober 2010 yang bertempat di Sewon, Yogyakarta. Setelah pembuatan studio radio, dua bulan berikutnya dilakukan persiapan-persiapan terkait manajemen dan penyelenggaraan-penyelenggaraan program, hingga pada bulan Januari 2011, Radio Boekoe memasuki tahap uji coba dengan mulai melakukan siaran secara online. Pemilihan radio online sebagai titik akses informasi dengan menginisiasi media hibrida dalam pelaksanaannya dikarenakan menjamurnya pengguna internet di Indonesia, sehingga dengan pertimbangan tersebut, kumandang literasi yang diusung Radio Boekoe dapat diakses oleh individu-individu dalam masyarakat dengan leluasa, tanpa batasan ruang dan waktu.

Pemanfaatan live streaming radio juga menjanjikan proses penyimpanan yang lebih baik. Materi siaran yang dibuat berbasis cloud computing dengan menggunakan aplikasi sound cloud, memungkinkan materi siaran diabadikan sebagai arsip suara di bawah pengelolaan Warung Arsip, sehingga semua arsip-arsip suara hasil siaran Radio Boekoe dapat diakses kembali oleh book lovers, sebab dengan konsep streaming, semua materi siar harus direkam terlebih dahulu dan disimpan pada media penyimpanan berbasis cloud computing. Proses inilah yang secara tidak langsung telah turut berkontribusi dalam proses dekonstruksi titik akses informasi pada buku, dalam wujud pengabadian dan perluasan titik akses informasi, sebab hasil rekaman siaran Radio Boekoe tersebut tersimpan hingga jangka waktu tak terhingga dan dapat dimanfaatkan kembali sampai kapan pun. Proses akses informasi juga tidak lagi bergantung dengan rentang waktu tertentu.

Radio Boekoe terus berkembang. Berbagai fasilitas siaran pun terus disempurnakan. Proses pengadaan perlengkapan di radio buku tidak langsung dapat dipenuhi seketika, namun secara bertahap. Perlengkapan pertama yang disiapkan adalah komputer yang akan digunakan dalam penyusunan administrasi siaran, pembuatan rencana program siaran dan media penyimpan data rekaman siaran. Selanjutnya dilengkapi dengan mixer untuk melakukan proses rekaman. Hal ini dikarenakan faktor pendanaan yang bersifat swadana dari para penggagas Radio Boekoe.

Meskipun pendanaan dilakukan secara swadana, Radio Boekoe terus mengusahakan akses informasi seluas mungkin bagi masyarakat. Hal tersebut ditunjukkan dengan mendorong perkembangan program acara yang dimiliki Radio Boekoe. Program acara Radio Boekoe meliputi Buku Pertamaku, Angkringan Buku, Katalog Seni, Komunitas, Cine Book, Cerita Bersambung, Kanon Sastra (Pembacaan Karya Sastra), Kabar Buku, Jurnal Republik, Kronik Indonesia, Buletin Suara Buku, serta bedah buku dengan penulis-penulis yang baru menghasilkan sebuah karya sebagai ajang promosi bagi penulis tersebut. Berbagai acara yang dilakukan oleh Radio Boekoe tersebut, merupakan sebuah proses untuk menciptakan arsip suara dari setiap buku yang dibahas atau dibedah yang kemudian disiarkan melalui media radio untuk proses diseminasi atau penyebarluasan informasi kepada para pendengarnya.

Proses pengarsipan rekaman suara dari pembacaan buku dilakukan dengan cara menyimpan pada kepingan Compact Disk (CD), external hard disk dan juga pada website radio buku yang terkoneksi langsung dengan aplikasi sound cloud. Penyimpanan pada website ini merupakan bagian dari konsep live streamingdan juga penerapan konsep erepository. Hal ini bertujuan agar arsip rekaman dapat diakses dan didengarkan sampai kapan pun dan di mana pun, tidak terbatas hanya pada saat siaran berlangsung. Untuk memudahkan proses penelusuran atau temu balik file rekaman, pengelola radio buku melakukan penamaan file rekaman dengan dua cara yaitu menggunakan tanggal proses rekaman dan nama kegiatan untuk rekaman berbagai event yang pernah berlangsung serta menggunakan tanggal proses rekaman, nama penulis buku dan judul buku untuk rekaman suara buku.

Proses perekaman arsip suara dilakukan di ruang siaran radio buku. Proses tersebut dilakukan oleh para volunteer yang kemudian dibuat playlist yang nantinya akan digunakan 
sebagai bahan siaran radio buku pada jam 13.00 WIB sampai dengan pukul 22.00 WIB setiap harinya. Dalam proses siaran tersebut tidak hanya menyiarkan seputar buku saja, tetapi juga memutarkan lagu-lagu, seperti yang lazim dilakukan pada siaran-siaran radio pada umumnya untuk menghidupkan suasana. Pemilihan buku dan lagu-lagu yang disiarkan disesuaikan dengan tema siaran, permintaan dari narasumber dan juga permintaan dari pendengar radio buku (live request).

Pada awal tahun 2011, ketika eksistensi media radio masih diperhitungkan, menjadi keuntungan tersendiri pada proses penyebaran informasi tentang buku yang dilakukan Radio Boekoe, yang menunjukkan efisiensi dan efektifitas upaya literasi bagi masyarakat oleh Radio Boekoe melalui program-program siarannya. Hal ini ditunjukkan dengan respon dan animo dari para pendengar Radio Boekoe yang baik dan juga jumlah volunteer dari Radio Boekoe yang pada setiap periode pembukaan recruitment selalu banjir pelamar, bahkan hingga mengharuskan Radio Boekoe melakukan seleksi dalam proses volunteer recruitment.

Para volunteer tersebut mayoritas merupakan pendengar setia radio Boekoe atau yang sering disapa sebagai book lovers, yang telah merasakan manfaat informasi yang coba disebarkan oleh Radio Boekoe lewat berbagai acara baik berupa off aired event maupun berbagai program-program on aired Radio Boekoe. Manfaat perolehan informasi yang disebarkan Radio Boekoe dan dirasakan oleh para volunteer tersebut pada akhirnya mendorong keingintahuan mereka untuk mengenal lebih dekat Radio Boekoe dari sudut pandang dapur siaran hingga proses manajemen pengelolaan Radio Boekoe dalam menyelenggarakan program-program penyebarluasan informasi tentang buku kepada masyarakat pendengar.

Berkaca dari animo serta antusias book lovers yang ingin menjadi volunteer, pihak manajemen Radio Boekoe melihat sebuah peluang baru untuk mengembangkan program Radio Boekoe dengan mencoba menyajikan manfaat yang lebih bagi para book lovers, terutama bagi para volunteer dengan memberikan kesempatan untuk memperdalam keterampilan dalam menulis sebagai bentuk pemanfaatan informasi yang telah diperoleh dari Radio Boekoe dengan mewajibkan setiap angkatan volunteer membuat tulisan yang kemudian diterbitkan menjadi sebuah buku. Hal ini dilakukan agar informasi tidak sekedar disebarkan, namun manfaat informasi itu sendiri menjadi lebih nyata dengan munculnya produk pengetahuan yaitu buku yang ditulis para volunteer. Hingga saat ini, Radio Boekoe telah menerbitkan lima buah buku hasil tulisan para volunteer.

Para volunteer Radio Boekoe yang merupakan book lovers dari berbagai kota ini merupakan bentuk hasil sebuah proses dekonstruksi titik akses diseminasi informasi yang dilakukan oleh Radio Boekoe, yang mana Radio Boekoe sebagai sumber dari informasi mengenai buku menyebarluaskan informasinya menggunakan media radio dan telah memperoleh respon positif sebagai feedback proses diseminasi informasi tentang buku yang dilakukan oleh Radio Boekoe. Keberadaan book lovers dan para volunteer Radio Boekoe merupakan bukti otentik titik-titik akses diseminasi informasi tentang buku yang coba didekonstruksi oleh para penggagas Radio Boekoe. Informasi yang semula hanya tertuang secara tekstual dalam lembaran-lembaran halaman buku dan sulit diakses karena membutuhkan waktu khusus untuk membaca, diubah ke dalam bentuk audio, yang mana lebih menjanjikan fleksibilitas akses informasi, dalam arti tidak membutuhkan waktu khusus untuk mengakses informasi, atau dengan kata lain informasi tentang buku sebagai ciri khas program-program acara Radio Boekoe, dapat diakses sambil mengerjakan pekerjaan lain.

Upaya Radio Boekoe untuk memperluas akses informasi belum mencapai kesudahannya, justru upaya tersebut mendorong Radio Boekoe memasuki level berikutnya saat animo pelamar volunteer Radio Boekoe semakin bertambah setiap tahunnya. Fenomena peningkatan jumlah book lovers yang berminat menjadi volunteer memberi sinyal kuat bagi Radio Boekoe untuk melebarkan sayap menjangkau titik akses 
informasi yang lebih luas. Berawal dari ketertarikan para book lovers untuk mengenal dapur siaran Radio Boekoe, pihak manajemen Radio Boekoe melihat potensi titik akses diseminasi informasi baru untuk memasuki level yang lebih lanjut yaitu pada tataran penggunaan pengetahuan, yang mana pada saat seseorang memperoleh informasi, yang lambat laun terakumulasi menjadi pengetahuan, maka secara natural akan mendorong seseorang tersebut untuk menggunakan atau mengaplikasikan kumpulan informasi yang telah menjadi pengetahuan dalam benaknya tersebut (Sudarsono, 2017). Peluang potensi inilah yang kemudian dimanfaatkan oleh pihak manajemen Radio Boekoe pada program magang bagi para volunteer.

Para volunteer tidak sekedar dilibatkan pada proses siaran dan pengelolaan arsip suara hasil rekaman dan siaran yang dilakukan, tetapi sebagai proses akhir magang, para volunteer diwajibkan memberi kenang-kenangan berupa tulisan tentang hal apapun yang mereka minati dan mereka rasakan dari proses interaksi mereka dengan informasi-informasi yang mereka peroleh dari Radio Boekoe. Hasil tulisan para volunteer tersebut kemudian diterbitkan menjadi sebuah buku antologi. Buku hasil karya para volunteer Radio Boekoe tersebut merupakan bentuk ekspresi akumulasi informasi yang mereka peroleh selama berinteraksi dengan titik-titik akses informasi yang dibangun oleh Radio Boekoe. Buku hasil karya para volunteer Radio Boekoe juga merupakan bentuk implementasi dekonstruksi titik akses informasi, yang semula hanya pada tataran penyebarluasan atau diseminasi, meluas pada tataran penggunaan atau pengaplikasian informasi itu sendiri, dalam wujud ekspresi tulisan yang merupakan sumber informasi baru serta titik baru akses informasi.

Namun seiring berjalannya waktu dan perkembangan teknologi yang semakin pesat, dalam kurun waktu enam tahun sejak pertama dirintis (2011-2017), Radio Boekoe menghadapi tantangan baru berupa determinasi teknologi informasi dan komunikasi, yang mana hal tersebut turut merubah wajah dunia media massa, termasuk radio. Seiring perkembangan teknologi informasi dan komunikasi, media massa konvensional mulai kalah pamor dengan kemunculan media-media diseminasi informasi berbasis internet yang lebih diminati khalayak masyarakat. Menurunnya jumlah penikmat media diseminasi informasi konvensional seperti siaran radio dan siaran televisi yang berbasis frekuensi gelombang siar mendorong pihak manajemen Radio Boekoe untuk memutar otak agar tidak kehilangan pendengar yang menjadi penikmat informasi tentang buku yang menjadi unggulan Radio Boekoe.

Pihak manajemen Radio Boekoe pada akhirnya mencapai kata sepakat untuk menghentikan proses siaran secara live dan lebih berkonsentrasi pada proses pengarsipan suara di bawah divisi Warung Arsip sebagai bentuk penguatan titik akses informasi berbasis audio. Arsip-arsip suara tersebut kemudian disebarluaskan melalui website Radio Boekoe dengan memanfaatkan cloud computing yang tersaji dalam menu "Suara Buku". Menu "Suara Buku" yang berisi rekaman-rekaman hasil kemas ulang teks buku yang dibacakan sehingga informasi di dalam buku dapat dinikmati via suara, menjawab tantangan determinasi teknologi yang dihadapi media siar konvensional yang pada umumnya hanya dapat dilakukan secara live.

Metode siaran baru melalui "Suara Buku" menunjukkan upaya dekonstruksi akses informasi yang dilakukan Radio Boekoe sebagai bentuk jawaban tantangan determinasi teknologi yang berdampak langsung pada perubahan media diseminasi informasi. Langkah adaptif Radio Boekoe dengan mengakomodir media hibrida berbasis cluod computing merupakan langkah nyata Yayasan Indonesia Buku dalam proses dekonstruksi titik akses informasi yang terbukti mampu memperluas titik akses informasi hingga tidak terbatas pada konteks suatu ruang dan waktu tertentu.

Dekonstruksi titik informasi dengan mengakomodir media hibrida merupakan solusi solutif untuk mempertahankan eksistensi distributor informasi. Hal ini pula yang disadari sepenuhnya oleh Radio Boekoe. Sebagai institusi yang bergerak di bidang literasi, sosial, 
dan kebudayaan, Radio Boekoe didirikan dengan semangat membangun budaya literasi melalui riset dan pengarsipan. Radio Buku dalam kerangka kerja pengarsipan yang telah memiliki produk layanan berupa perpustakaan komunitas, arsip suara, penerbitan indie, dan toko buku, pada pertengahan tahun 2018 mulai semakin fokus mengarahkan perhatiannya untuk memperluas titik-titik akses informasi kepada masyarakat, memulai inisiasi baru dengan menambah kapasitas melalui konsep coworking space.

Langkah inisiasi baru co-working space dilakukan dalam rangka mendukung iklim interaksi dan kolaborasi antar anggota komunitas, yang mana embrio inisiasi baru ini sebenarnya telah dimulai sejak Radio Boekoe dirintis pada tahun 2011, tepatnya saat dilakukan volunteer recruitment. Animo pendaftar yang terus meningkat setiap tahunnya, pada akhirnya membuahkan pemikiran untuk mengadakan program "bengkel menulis" bagi para volunteer Radio Boekoe. "Bengkel menulis" inilah yang menjadi puncak proses dekonstruksi titik akses diseminasi informasi, yang mana mulai menarik titik-titik diseminasi informasi hasil proses dekonstruksi menuju pada tahap pengaplikasian pengetahuan, yang diwujudnyatakan dengan proses penulisan buku.

Yayasan Indonesia Buku yang pada awalnya hanya berkonsentrasi pada proses penyimpanan sumber daya informasi pada perpustakaan "Gelaran Ibokoe" dan "Warung Arsip", perlahan mulai mengembangkan arah pandang melalui proses dekonstruksi titik akses diseminasi informasi dengan menggunakan media hibrida dalam wujud Radio Boekoe, yang terbukti mampu menyebarkan informasi dengan tidak terpaku pada ruang dan waktu tertentu. Penikmat informasi yang disebarluaskan Yayasan Radio Buku, tidak lagi hanya berasal dari Yogyakarta saja, hal ini semakin dikuatkan dengan adanya animo pelamar volunteer dari luar kota Yogyakarta. Kumandang literasi yang disiarkan Radio Boekoe pun bahkan sampai ke telinga pendengar yang ada di luar negeri, sehingga tak jarang warga negara asing pun bertandang ke studio Radio Boekoe. Penyebarluasan informasi yang dilakukan Yayasan Indonesia Buku melalui Radio Boekoe mampu menghilangkan batas ruang dan waktu dalam proses diseminasi informasi, yang pada akhirnya mengundang lebih banyak individu untuk mengembangkan kolaborasi dalam kerangka mengembangkan literasi bagi masyarakat, yang berujung pada ruang kerja bersama (co-working space) sebagai alternatif bekerja dan berjejaring masa kini.

Radio Boekoe melakukan inisiatif mengembangkan ekosistem, sumber daya, perangkat bersama dan shared space dalam konsep co-working space guna mengntegrasikan sumber daya informasi yang tersimpan di perpustakaan, kerja pengarsipan "Warung Arsip", dan kegiatan penerbitan dalam satu area menjadi bentuk model co-working space yang diimplementasikan di Radio Boekoe. Salah satu model co-working space yang coba dikonstruksi di Radio Boekoe Yogyakarta adalah "laboratorium penulis", yang semula hanya sebagai "bengkel menulis" para volunteer, dengan inisiasi konsep coworking space kini mulai memperluas kapasitasnya sebagai ruang publik bagi seluruhbook lovers berkolaborasi dalam komunitas untuk menghasilkan karya baru.

Radio Boekoe yang telah menginisiasi konsep co-working space sebagai suatu "laboratorium penulis" berfungsi layaknya melting pot, bergerak mengumpulkan para penulis baik pemula maupun penulis senior untuk berdiskusi perihal kegiatan menulis. Mulai dari proses merumuskan tema, kegiatan menyunting (editing), sampai tahap menerbitkan buku. Radio Boekoe telah menyadari bahwa penyebarluasan akses informasi, tidak dapat berhenti hanya pada titik global dissemination. Kesuksesan dari kumandang literasi yang diupayakan Radio Boekoe telah disadari oleh para penggagasnya terjadi pada saat informasi yang disebarkan seluas-luasnya dan seglobal mungkin tersebut, tidak hanya sekedar diterima oleh masyarakat luas, tetapi informasi yang diterima tersebut dapat dimanfaatkan para penerimanya untuk 
menghasilkan titik informasi baru melalui munculnya karya-karya baru yang sarat dengan informasi baru.

Radio Boekoe yang telah memahami tujuan utama diseminasi informasi, menunjukkan keseriusannya dengan memperbaiki fasilitas ruang-ruang publik di Radio Boekoe atau yang disebut dengan nama co-working space Bale Black Box, yang telah dilengkapi dengan berbagai fasilitas perangkat penerbitan mandiri meliputi meja kerja, alat scanning, peralatan komputer, dan printer. Fasilitas co-working space di Radio Boekoe juga dilengkapi dengan koneksi internet yang stabil, proyektor dan layar proyeksi, papan tulis, pelantang dan sistem suara, listrik $3.2 \mathrm{~K}$ watt, serta dapur makanan dan minuman yang diharapkan dapat menunjang proses diskusi-diskusi dalam ruang karya kolaborasi di Bale Black Box. Tidak hanya berhenti pada ketersediaan ruang kolaborasi karya, buku-buku yang dihasilkan "laboratorium penulis" tersebut pada akhirnya didistribusikan kembali pada masyarakat luas melalui online maupun offline store di bawah pengelolaan Yayasan Indonesia Buku dengan harapan dapat kembali memicu pembacanya untuk menghasilkan karya-karya baru.

Upaya Yayasan Indonesia Buku yang dimulai dengan proses pengumpulan dan penyimpanan sumber daya informasi melalui perpustakaan dan Warung Arsip perlahan bertransformasi menuju arah pemberdayaan sumber daya informasi bagi masyarakat melalui inovasi layanan yang mengakomodir media hibrida yaitu Radio Boekoe sebagai media penyebaran informasi hingga titik akses global. Upaya tersebut pada akhirnya menyebabkan munculnya kebutuhan ruang kolaborasi karya. Peluang baru berupa ruang karya kolaborasi sebagai dampak determinasi teknologi tersebutbermanfaat sebagai faktor yang memicu proses dekonstruksi titik akses informasi. Faktor pemicu tersebut juga mampu mendorong peran Yayasan Indonesia Buku lewat kumandang literasi Radio Boekoe, untuk terus menerus melakukan proses dekonstruksi titik akses diseminasi informasi dengan mengusung konsep co-working space Bale Black Box. Hal tersebut membuat informasi tidak lagi sekedar diterima oleh masyarakat, tetapi juga dimanfaatkan untuk menghasilkan karya-karya baru, sehingga siklus pengetahuan yang ada di tengah masyarakat dapat terus terjaga kesinambungannya.

\section{E. KESIMPULAN}

Radio Boekoe merupakan wujud titik akses hasil dekonstruksi Yayasan Indonesia Buku. Yayasan Indonesia Buku yang pada awalnya melakukan konstruksi titik akses diseminasi informasi dengan membangun perpustakaan komunitas di jalan Patehan, perlahan melakukan proses dekonstruksi titik akses informasi dengan menyelenggarakan Gelaran Iboekoe. Proses dekonstruksi selanjutnya dilakukan dengan menginisiasi media hibrida dalam wujud Radio Boekoe. Radio Boekoe berhasil menyebarkan titik akses diseminasi informasi Yayasan Indonesia Buku secara global, yang pada akhirnya memunculkan kebutuhan baru masyarakat terhadap akses informasi pada ranah pengaplikasian pengetahuan dalam wujud kebutuhan ruang kolaborasi. Hal ini pada akhirnya memicu Yayasan Indonesia Buku melanjutkan proses dekonstruksi titik akses diseminasi informasi, yang semula hanya mengupayakan titik akses seglobal mungkin, berubah menjadi upaya akses kolaborasi karya dengan membentuk co-working space Bale Black Box Radio Boekoe. Pembentukan coworking space tersebut merupakan langkah yang ditujukan untuk memfasilitasi kebutuhan masyarakat dalam menghasilkan karya-karya baru sebagai titik-titik baru akses informasi dalam wujud hasil karya cipta.

\section{DAFTAR PUSTAKA}

Almanshur, F. \& Djunaidi, G. (2012). Metodologi penelitian kualitatif. Yogjakarta: Ar-Ruzz Media.

Sudarsono, B. (2017). Menuju era baru dokumentasi. Jakarta: LIPI Press.

Chadwick, A. (2013). The hybrid media system: Politics and power. New York: Oxford University Press.

Gunawan, I. (2015). Metode penelitian kualitatif: Teori dan Praktik. Jakarta: Bumi Aksara. 
Leeuwis, C. (2013). Communication for rural innovations: Rethinking agricultural extension. New Jersey: John Wiley and Sons.

Marchetti, R. \& Ceccobelli, D. (2016). Twitter and television in a hybrid media system. Journalism Practice, 10(5), 626-644. https://doi.org/10.1080/17512786.2015.10 40051

McLuhan, M. (2017). The Guttenberg galaxy. Toronto, Canada: Toronto Press.

Moleong, L. J. (2013). Metode penelitian kualitatif. Bandung: PT. Remaja Rosdakarya.

Nasrullah, R. (2015). Media sosial: Perspektif komunikasi, budaya, dan sosioteknologi. Bandung: Simbiosa.

Ruben, B. D. (2017). Between communication and information. London: Routledge.

Saputro, R. M. (2011). Determinisme teknologi: Kajian filsafat mengenai pengaruh teknologi terhadap perkembangan masyarakat. Tesis. Depok: Universitas Indonesia.

Saepudin, E., Damayani, N. A., \& Rusmana, A. (2018). Model literasi budaya masyarakat Tatar Karang di Kecamatan Cipatujah Kabupaten Tasikmalaya. Berkala Ilmu Perpustakaan dan Informasi,14(1), 1-10. https://doi.org/10.22146/bip.33315.
Straubhaar, J., LaRose, R., \& Davenport, L. (2015). Media now: Understanding media, culture, and technology. Massachusetts: Cengage Learning.

Sugiyono. (2011). Metode penelitian kuantitatif, kualitatif, dan $R \& D$. Bandung: Alfabeta.

Surahman, S. (2016). Determinisme teknologi dan komunikasi. Jurnal Rekam, 12(1), 31-42.

Utami, E. (2017, 4 Mei). IBOEKOE: Aktif siarkan buku melalui darat dan udara. Komunita.id. Diunduh dari https://komunita.id/2017/05/04/iBoekoeaktif-siarkan-buku-melalui-darat-danudara/.

Widjanarko, W., Sulthan, M., \& Lusiana, Y. (2013). Radio siaran publik sebagai media komunikasi perguruan tinggi dalam pemberdayaan masyarakat pedesaan. Jurnal Kajian Komunikasi, 1 (2), 119-124.

Yin, R. K. (2014). Studi kasus: Desain dan metode. Jakarta: Rajawali Pers. 


\section{DAFTAR GAMBAR}

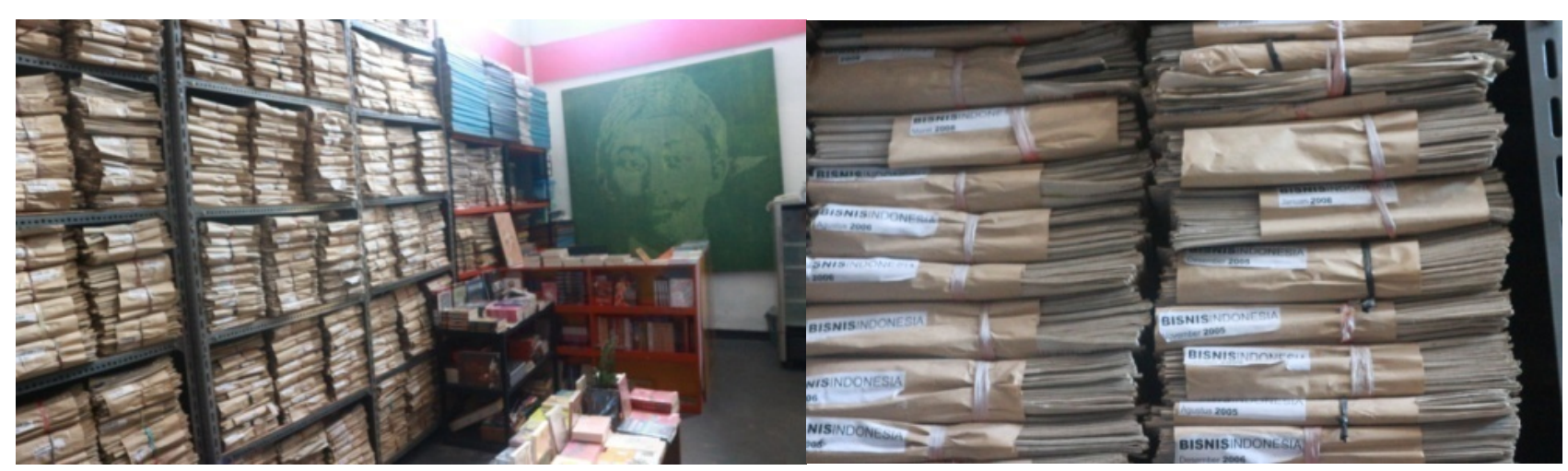

Gambar 1. Arsip Koran di Radio Boekoe

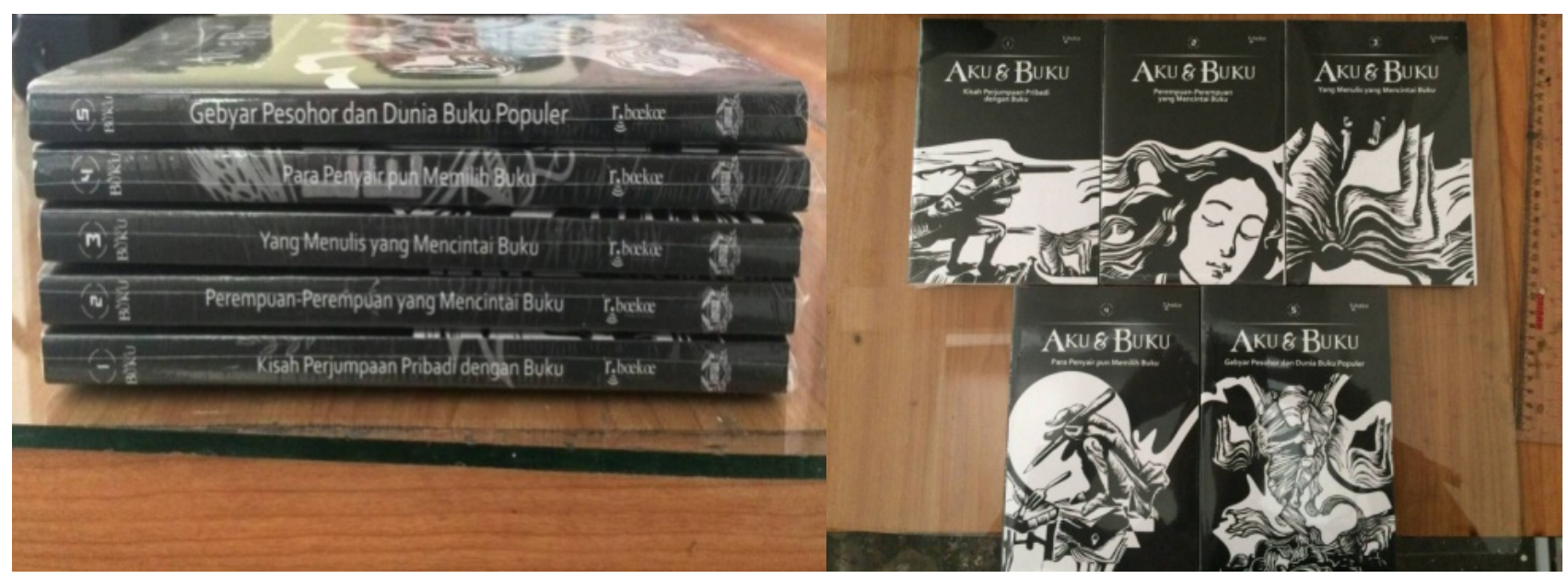

Gambar 2. Buku Antologi Hasil Karya Volunteer Radio Boekoe

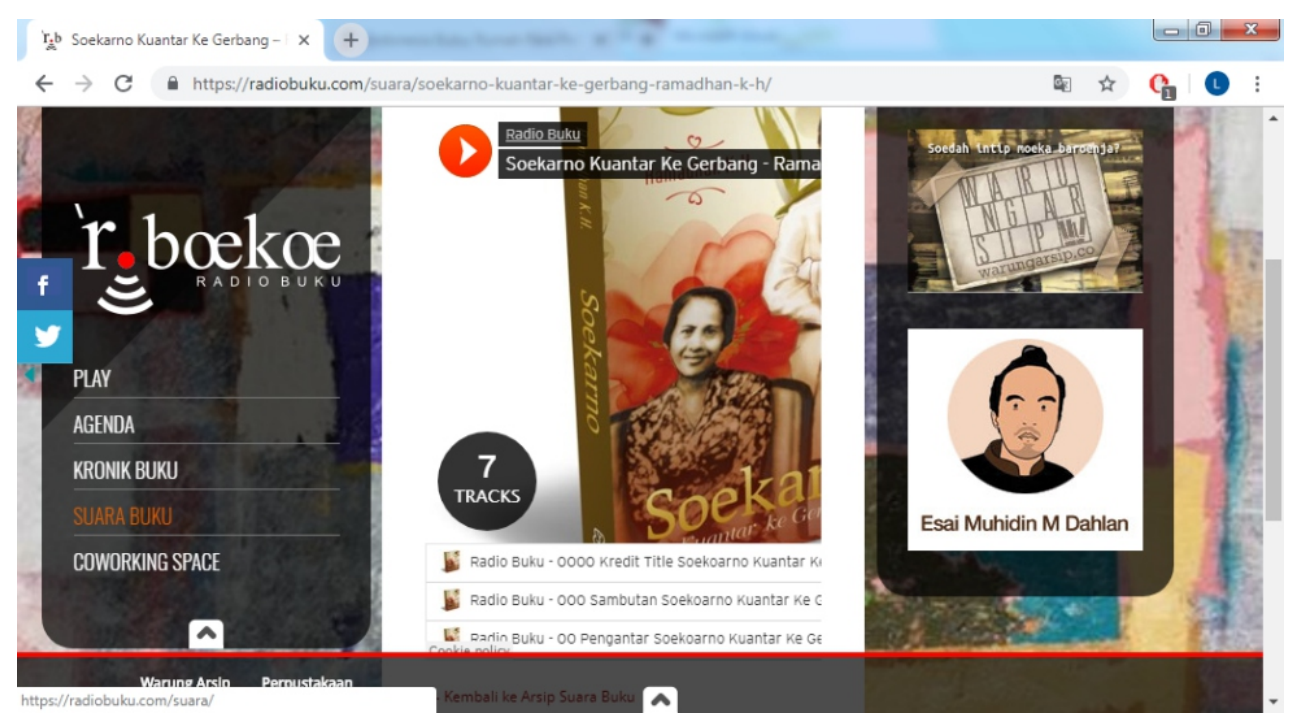

Gambar 3. Tampilan "Suara Buku” pada Website Radio Boekoe 


\section{DAFTAR GAMBAR}

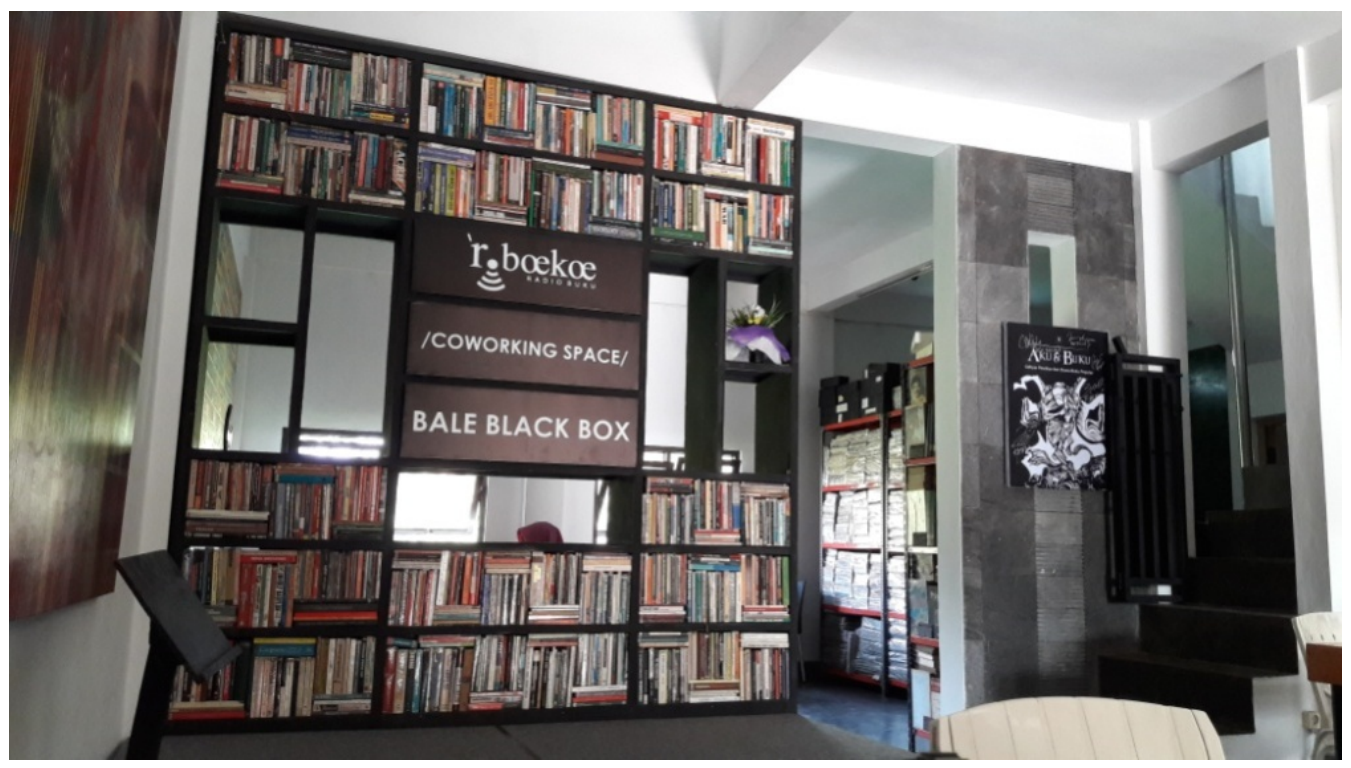

Gambar 4. Co-working Space Bale Black Box di Radio Boekoe 